\title{
The Moorish Science Temple of America
}

\author{
Fathie Ali Abdat
}

\section{1 Introduction}

Scholars of African-American Islam usually view the Moorish Science Temple of America as a peculiar religious sect. ${ }^{1}$ This is understandable given the treacherous terrain that must be traversed to understand the Moorish ${ }^{2}$ Science Temple of America (henceforth MSTA). Early source materials on the movement remain scant, its religious creeds tangled in esoteric eclecticism, and their followers' narrations bewilderingly conflict one other. Yet, it remains vital to critically examine the MSTA given its significance as one of the earliest pan-American Islamic organisations in the twentieth century, one that influenced other communities it came into contact with. Thus, Edward Curtis IV, a doyen of African-American Islamic studies, has advocated the need for a re-examination of the MSTA through a more critical lens of "cultural history" and away from the straightjacket of it being a deviant heretical group (Curtis IV 2009). This chapter takes up this challenge by analysing the MSTA at the interstices of hagiography and heresiography and historicising how the MSTA as a genuine spiritual community reinvented and restyled its orientation over the decades through its ebbs and flows in its quest for respectability, relevance, and salvation.

1 I am indebted to several individuals for their unwavering support in my study of this religious movement. Patrick D. Bowen was extremely generous in sharing his repository of primary and secondary source materials on this movement. I also extend my sincerest appreciation to Professor Jacob Dorman for rekindling my academic interest in African-American Islamic history. Along this journey, I feel humble to have had countless Moorish Science Temple of America believers share with me their stories, experiences and histories. In particular, Sharif Anael-Bey has been very helpful to me in the writing this chapter.

2 Within the literature of the movement, the term 'Moor' is an elastic, amorphous identitysignifier that concomitantly refers genealogically (to the ancient Biblical community of Moabites), historically (to the golden age of Islamic Iberian Peninsula during the Middle Ages) and geo-politically (to the modern nation-state of Morocco). 
Most literature on the founding prophet of the Moorish Science Temple of America (MSTA), Noble Drew Ali (1886-1929), has either treated his murky origins cursorily or hagiographically exaggerated and romanticised his roots. Recent fortuitous discoveries of Drew's pre-Moorish documents have enabled historians to reconstruct a more empirical account of the Moorish prophet. While tampering with Drew's legacy could open a Pandora's box, with unforeseen circumstances that would bring no discernible benefit to contemporary Moorish-American Sheiks, the MSTA laity deserves knowledge of its genuine historical past unencumbered from crudely constructed myths (Wilson 1993).

Newly unearthed census and city records disclosed that dogmatic MSTA narrations on Drew's genealogical roots were specious. Drew Ali was born Thomas Drew on January 8, 1886 in Norfolk, Virginia. By 1898, he was adopted by James Washington Drew and Lucy Drew, an African-American couple residing in 411 Princess Anne Avenue, Norfolk, Virginia (United States Federal Census 19oo). As a teenager, the illiterate Drew worked as a common labourer, rural farmhand, and wharf longshoreman in the southern port city to supplement his adopted parents' wages (Abdat 2014). However, like many black Norfolk laborers, the Drews were paid little, and could not catapult themselves into the black bourgeois class.

As such, Drew explored new prospects in other cities plying his trade first as a porter in Richmond, Virginia in 1916 and then as a shipyard labourer for the Submarine Boat Corporation in Newark, New Jersey, answering America's call in the industrial war effort. On September 12, 1918, Drew reported to a public school in Bruce Street, Newark, New Jersey for the Third Draft registration as part of the volunteer-conscripted American army in the Great War. A routine medical examination revealed "badly burnt" forearm muscles (United States wwi Draft Registration Card 1918) and Drew subsequently failed the criteria for induction. After World War I, the company folded leaving Drew unemployed.

In large part, between 1916 and 1923, Drew resided in 181 Warren Street, Newark, New Jersey together with Louisa Gaines, a married Virginian, in a mixed neighbourhood. Drew alternated between working in a barber shop and as "street preacher" (United States Federal Census 1920). For the latter, Drew attired himself in a loosely fitting multi-colored gown, covered his head with a brilliant purple hood and cosmetically redesigned himself as "Professor Thomas Drew, the Egyptian Adept Student," an East Indian from Virginia who ate nails and cured blind soldiers. His vast clientele sought him for a wide range of services including crystal-gazing, advice on love-affairs, and eastern wisdom such as the forgotten eighteen years of Jesus Christ's life. Swiftly he emerged as black 
Newark's leading faith healer amidst the crowded (and competitive) religious market place of seers, mystics, palmists, professors and princes who taught mystical sciences since the turn of the twentieth century (Dorman 20o9). At this juncture, Drew was still un-fezzed, unaffiliated to a Moorish lineage, but had already fashioned himself as a true Orientalist Muslim. Nevertheless, during this phase Drew fell afoul of the law several times, and was arrested for illegally peddling medicine.

Despite trumpeting messianic claims of his ability to "bend (prison) bars" (Newark Evening News 1916), Newark's federal penitentiary successfully quarantined Professor Drew physically in the late 1910s and early 1920s. Yet, prison walls failed to totally circumscribe Muslim teachings in Newark, as another enigmatic figure took Drew's position to further fan the flame of esoteric folk Islam in the community. With Drew's religious preaching in abeyance, Abdul Hamid Suleiman (b. 1864-?), a Sudanese immigrant, filled the mantle as a charismatic spiritual leader serving Newark's coloured community. Suleiman founded an extremely successful Canaanite Temple, a black Mohammedan-Masonic movement that operated in various cities including one at the corner of Bank and Rutgers Streets, Newark, a mere three miles from his residence (Bowen 2011). In April 1923, the popularity of Suleiman's Canaanite Temple spectacularly nosedived when Suleiman and his assistant Muhammad Ali, were charged and arrested by the Supreme Court of New Jersey for carnal abuse of a follower's child.

Amidst the leadership vacuum, Professor Drew reinvented himself as a religious prophet by deliberately suffixing the powerful surname Ali, that concomitantly connected him to three important sources of authority in the minds of black urban masses: Caliph Alee (599-661), the imagined founding father of Masonry and son-in-law of Islamic Prophet Muhammad ibn Abdullah; Duse Muhammad Ali (1866-1945), an inspirational pan-Africanist Garveyite intellectual; and the incarcerated Mohammed Ali, local organiser for the Canaanite Temple. As Canaanite Temple No. 1 had legally been incorporated in Newark in May 1924, Drew embarked on an evangelical crusade elsewhere under a new Moorish banner, to re-structure Suleiman's satellite temples and travelled to several Southern cities before establishing his headquarters at Chicago, Illinois in 1925 .

As Drew's sense of Islamic-consciousness was stirred through an embodied experience with Oriental street healers and Canaanite-Masonic esotericism, Drew's understanding of Islam was imagined-yet-authentic when contextualised through the lens of its gestation. By corollary, Sunnī sceptics who uncritically vilify Drew for deviating from Muhammad ibn Abdullah's finality of prophethood have somewhat misdirected their accusation, since they have 
overlooked that Drew's adoption of the titles 'Noble' and 'Prophet' were borrowed from Masonic circles, and not ever intended to be an affront to Sunnī orthodoxy (Abu Shouk, Hunwick and O'Fahey 1993).

Though MSTA followers believe the historical process underpinning the establishment of the MSTA as a religious organisation was forged along an uncomplicated linear trajectory, this was a façade. Rather, Drew's inchoate MSTA between 1925 and 1929 underwent capricious and erratic shifts as the founder experimented and cobbled together various ideological fragments of his highly eclectic movement. The MSTA's mutable vagaries were clearly reflected as his Moorish movement underwent a series of name changes. Initially, Drew formally incorporated the Moorish Temple of Science on 29 November 1926 as a civic organisation on 3603 Indiana Avenue, Chicago, Illinois, to "uplift fallen humanity" and "teach men and women to become better citizens" (Ali 1926).

Structurally, Drew was inspired by Garvey's Universal Negro Improvement Association (UNIA), hence modelling the MSTA along Garveyite lines of ancillary units like the Moorish Manufacturing Corporation, the Moorish Guide and the Sisters National Auxiliary (Haddad and Smith 1993). Drew perspicaciously linked his incipient organisation to Garvey's by embedding the popular UNIA leader in the trope of John the Baptist, a forerunner who prophesised Drew's advent. Theologically, Drew looked to Abdul Hamid Suleiman's Canaanite Temple novel blueprint of a black Islamic Masonry (Bowen 2014). Though Drew substituted Suleiman's Mecca with Morocco as the main cosmological centre of spiritual power, Drew appropriated Suleiman's taxonomy that bifurcated Islam for blacks and Christianity for whites. This unique Mohammeddan-Masonic nexus premised on a romanticised pan-African and pan-Islamic genealogical identity anchored the MSTA ideology.

In compiling his main religious scripture, the Circle Seven Koran (henceforth CSK), Drew leveraged on his experience as an Oriental Asiatic Scientist in Newark as fodder. ${ }^{3}$ In Chapters 1 to 19 of Drew's Koran, he drew heavily from Levi Dowling's The Aquarian Gospel of Jesus the Christ (1908), an esoteric

3 The term 'Asiatic' is a nuanced racial-religious term often found in African-American Muslim communities in the twentieth century (for example, the Nation of Islam, Five Percenters, and the MSTA). While 'Asiatic' groups occasionally claim ties of affiliation with 'Asian' communities (such as the Japanese, Indian, Filipino, Vietnamese) in some cases, the term 'Asiatic' is divorced from 'Asian'. See N. Deutch, 2001, "The Asiatic Black Man: An African American Orientalism," Journal of Asian American Studies, 4:3, 193-208. 
theosophical text emphasising Christ's itinerant travels and encounters with other world religious figures, symbolising humankind's quest for universal spirituality. For Chapters 20 to 44 of CSK, Drew included sections from Unto Thee I Grant (1925) published by the Ancient and Mystical Order Rosae Crucis, a Rosicrucian group propagating moralistic, puritanical lives to achieve happiness and liberation in their worldly-state (Curtis IV 2002).

While Drew was aware of mainstream Islamic tenets from Ahmadiyya Muslim literature produced out of South Wabash, Chicago, and evangelical censures from Satti Majid, a Sudanese missionary, the Moorish leader warilybut-pragmatically steered clear of Islamicising his movement, maintaining a hesitant embrace of orthodox Islam at best (Abu Shouk, Hunwick and O'Fahey 1993). Instead, Drew favoured a metaphysical disposition of Islam based on universal principles of "love, truth, peace, freedom, justice and equality" through a conversion to "Islamism" where neophytes swapped Christianity and blackness for a Moorish-American nationality, symbolised by taking on surnames of El and Bey (Ali 1928).

Yet the path towards forging a monolithic, pan-national movement was fraught with uncertainties. In January 1928, Drew and several aides travelled to Havana, Cuba to attend the 6th Pan American Conference to represent the nascent community. ${ }^{4}$ Nevertheless, prospects for a successful National Convention were hamstrung by a series of Temple fiascos. Between April to June, 1928, leaders in Pittsburgh Temple No. 5 and Richmond Temple No. 6 were arrested for practising bigamy, unlicensed medicine selling and seditious teachings (Bowen 2013). As authorities raided the temples, Drew retreated to Mexico and on his return, convened a special meeting to legally rename the movement as the "Moorish Science Temple of America" on 21 May 1928 to shield against allegations of conspiratorial subversion. The metamorphosis into a more patriotic-leaning organisation was completed a month later as the MSTA was formally re-incorporated as a religious organisation on 20 July 1928 that not only taught "loyalty to the nation and the deepest respect for law and order" but also dismissed notions of a "pilgrimage to some other country" (Ali 1928).

Following Drew's desperate organisational reshuffling, he travelled to Arkansas, Philadelphia, and West Virginia visiting his congregation to revive flagging Temples and appeal for financial assistance. To amplify his reach,

4 Though details of Drew's participation in this Cuban conference remain doubtful, a very interesting shipping record recently was discovered by Moorish-American followers that definitely verified that Drew Ali boarded the S.S. Northland vessel on 25 January 1928 to sail from Havana, Cuba back to the United States. 
Drew placed monthly articles in the Chicago Defender advertising an impending Moorish conclave featuring a parade led by pilgrims decked in Eastern regalia and updates of economic accomplishments. The efforts bore fruit such that by August 1928, Drew churned out the first edition of the Moorish Guide newspaper. Eventually, the momentum climaxed in the MSTA's First National Convention spanning five days from 15 to 20 October 1928 marking the apex of Drew's ascent as a respectable national religious figure as thousands of devotees from seventeen temples in fifteen different cities turned out (McCloud 1994). In turn, Chicago's politicians and businessmen gravitated closer to Drew, attracted by his mesmeric influence over his members. Drew, who had endorsed the candidacy of African-American city alderman Oscar De Priest during the Convention, contributed to the latter's achievement as the first person of African descent from a Northern state to serve in the House of Representatives, earning Drew an invite in the victory celebrations in November 1928. In February 1929, Drew urged his followers to successfully reelect Louis B. Anderson as Alderman in the 2nd Ward.

Paradoxically, the MSTA's exponential growth to 7,000 neophytes within a year proved too exhilarating for its own stability (Bowen 2017: 201-202). ${ }^{5}$ As the MSTA raked in huge revenues from membership fees, newspaper subscriptions and sales of medicinal products, this lured in shady characters who cultivated ties only for associations with adventure, fortune and opportunism. Amidst accusations of financial embezzlement, lascivious philandering and secessionist intrigues, Drew extricated top-brass Sheiks in Detroit, Chicago, and his Supreme Business Manager. This triggered first a Detroit Temple gunfight on 12 March, 1929 wounding two Moors and two police officers and then two days, a heinous assassination of the former business manager. Following the slaying, police officials raided Moorish temples, arrested Drew and hauled in other leaders for questioning on charges of being an accessory to homicide. At this juncture, the Chicago Defender radically revised their portrait of Drew from an authentic religious figure to a menacing charlatan. Still, faithful Moors rejected the demonisation of their prophet's moral credibility, instead demanding the police release Drew.

Though attorneys secured Drew's release temporarily on bail, the prophet passed away suddenly on 20 July 1929 in his home from tuberculosis bronchopneumonia, suspending criminal investigations and leaving bereaved followers despondent. Noble Drew Ali's elaborate funeral service orchestrated over a few days in late July 1929 proved the final occasion when different

5 Bowen arrived at this figure after meticulous calculations of early Moorish Guide temple numbers, financial membership fees and accounts by contemporary MSTA historians. 
Moorish Sheiks, Governors, and Adepts were united in grief. While Drew's apex proved fleeting, prematurely cut short by his death, the MSTA's exhilarating promises of connecting to a romanticised, Islamic-Moroccan community visà-vis uplifting message of socio-economic empowerment have transcended the founder's death by compelling many in the African-American community to question and re-evaluate long-held assumptions about the compatibility of their racial identity with their existing Christian, Jewish, or Sunnī Islamic faith-systems.

Following Drew's demise, historians of black American Islam like C. Eric Lincoln downplayed the movement's significance in the black community, citing its inevitable collapse owing to its fissiparous tendencies (Lincoln 1994). A rigorous scrutiny however disclosed that the MSTA edifice did not come crashing down. In fact, the supposed "collapse" myopically ignored the re-flowering of Moorish Islam characterised by an exponential proliferation of more than sixty MSTA Temples and an expanded membership with amplified political consciousness. Ironically, Drew's death in 1929 decentralised power and control beyond Chicago, prompting a mushrooming of Moorish theologians, whose textual revisionism of Drew's pre-1929 apocrypha in the rapidly changing 1930 s and 1940s socio-political environment, ushered in a second 'Moorish Silver Age' from 1929 to 1945 (Abdat 2015). This phase produced an inexhaustible reservoir of diverse Moorish-American modalities whose temples operated unique Moorish dispositions, each with different trajectories and only loosely held together by wildly charismatic leaders.

Undoubtedly, turbulent events from 1929 to 1931 between feuding Moorish leaders compromised Moorish unity. The leadership was riven with internecine squabbles in which politics and policies were inextricably fused. After Drew's obsequy, Supreme Grand Sheik Edward Mealy El (1870-1935), the most obvious candidate to inherit Drew's position based on organisational hierarchy, toured various Temples and embarked on a letter-writing campaign to Sheikhs and Adepts to desperately shore up the demoralised movement (Mealy-El 1931). Concurrently, Charles Kirkman-Bey (1896-1959), Drew's translator, colluded with other Sheiks to vote Mealy-El out of power during the contentious and Annual Convention on September 1929. This decision provoked Ira Johnson Bey (1879-1950), Drew's Pittsburgh-based enforcer, to kidnap Kirkman-Bey and seize leadership documents on 21 September 1929. But the scheme went awry, escalating into a deadly shootout between sixty Moors and the CPD. 
Throughout a protracted trial, lines of demarcation between diverse Moorish factions were clearly drawn. Kirkman-Bey, who took on the title Supreme Grand Advisor and Moderator (SGAM), filed legal suits against rivals who claimed to be Reincarnated Prophets for heretical innovation. Though the Circuit Court of Cook County legally awarded Drew's organisation to the SGAM in June 1935, such that he spearheaded the largest Moorish group, it was impossible for the SGAM to keep thousands of Moors dispersed across the nation's cities under effective control as they fluidly transcended boundaries across different Moorish factions, or independently carved out their own Moorish variant. The maddening confusion was exacerbated by followers' overlapping fealties, shape-shifting leaders, and non-exclusive relations between temples.

Apart from the SGAM, John Givens-El, Drew's former chauffeur, led a Reincarnated Moorish Temple faction whose followers distinguished themselves by being heavily bearded and perpetually fezzed. This group of Moors subscribed to the centrality of Drew's spirit entering Givens-El who fainted while working on the Prophet's car but mysteriously "had the sign of the star and the crescent in his eyes and they knew right then he was the prophet reincarnated into his chauffeur" (Marsh 2000: 35). After this religious epiphany, Givens-El fashioned himself as Noble Drew Ali II-'Mohammed Reincarnated'-but then found himself confined to a mental asylum for several years for his role in the leadership imbroglio. From behind prison bars, he successfully built up a significant puritanical faction with thousands of disciples in Chicago, Illinois, Philadelphia, Pennsylvania, Augusta, Georgia, Newark, New Jersey, and Baltimore, Maryland (Vale 1934: 20).

The third aspirant, Mealy-El, failed to make much headway in his challenge to unseat Kirkman-Bey. His letter-writing campaigns to convince Sheiks of his legitimacy and organisational credentials as Drew's rightful heir vis-à-vis Kirkman-Bey's duplicity fell on deaf ears until he passed away in 1935. Despite the struggles, Moorish-American relationships relatively stabilised after 1931 as each leaders grudgingly accepted their rivals' influence without directly confronting each other again.

In the 1930s and 1940s, all Moorish groups felt compelled towards exegetical revisionism owing to the rapidly changing domestic and international climate. The bombing of Pearl Harbour in December 1941 necessitated Moorish theologians to re-read, reinterpret, and refurbish Drew's 1920s doctrines to make sense of the turbulent events for their respective congregation. Noble Drew Ali's esoteric New Age wisdom had racially positioned the Japanese, alongside Egyptians and Arabians, amongst the divine Asiatic nations in the Circle Seven Koran. But Drew could not possibly have foreseen the permeating influence of Japan's Black Dragon Society propaganda, which cajoled 
black organisations in the 193 Os including the MSTA to embrace pro-Japanese, "black messianic" nationalistic proclivities in the event of a Japanese invasion of America (Allen, Jr. 1994). The Moorish faith-system became easily impregnated with external ideologies and influences demonstrating its porous boundaries.

Conversely, there was a need to determine MSTA's degree of patriotism towards America, since Drew's original attitudes had capriciously oscillated from brief seditious flirtations in 1928 to overt American fealty by 1929 . Confronted with Japanese agent provocateurs' propagandistic formulations of a rigid pan-Asiatic international order antagonistic towards Washington, Moorish-American theologians could no longer depend on Drew's anachronistic 1920s matrix of a double consciousness of constitutional adherence to America and a mytho-genealogical Asiatic brotherhood with the Japanese. Moorish-American theologians had to challenge the tired norms and cultural hangovers from the past.

All Moorish groups flirted with pro-Japanese revisionism, differing only in the degree and extent they acted on their beliefs. Kirkman-Bey's Temples quickly gravitated towards the draping of a Japanese pan-Asiatic blueprint over Drew's Asiatic Muslim core. Ever since 1936, his Hartford Moors hosted representatives from the Japanese Chamber of Commerce to propagate Japan's program for the new Asian order. In Bartholomew County, Indiana, Ruben Frazier Bey, a rural farmer adorned his living room with tapestry embroidered with a Black Dragon and Japanese scripture, transforming his home into a safety zone so "when the Japanese start bombing the United States, we will run up our flag and they will know we are their friends and won't bomb us [for those] who knew the symbols" (F BI MSTA File 1940).

In Flint, Michigan, Moors keenly awaited Drew's return and even took Major Satohata Takahashi, a Japanese agent provocateur, to be the prophet reincarnated. This influenced Flint Moors such as Rhodes-Bey to look towards the Japanese for survival in 1942 since they would provide nourishment as well as long-term job security believing the benevolent Japanese would "take over the plants here in Michigan and give them [to] the Moorish Science Temple and that everybody would have to work for us" (FBI MSTA File 1942). This position was hardly surprising considering the Moorish Voice constantly expounded on the genealogical-racial compatibility between Moors and the Japanese Army, demanding the former shape their glorious destiny alongside Japan, rather than remaining fatalistically passive awaiting Allāh to reverse the status quo. Ironically, within this Moorish-Japanese alliance Japan was repositioned above other Asiatics (including Moors), relegating the latter to a subordinate position within the Asiatic hierarchical order of races (Folsom-Bey 1942). 
The authorities' fears regarding the MSTA's treasonable proclivities heightened considerably from 1942, with increasingly frequent reports. In April, two Moorish leaders were arrested for coaxing African-Americans in Yazoo, Humphrey, Belzoni, and Milestone, Mississippi, not to register for Selective Service. Three months later, Father Prophet Mohammed Bey's Moors were arrested in Kansas City, Missouri, for evading Selective Service prompting the FBI Office to begin a thorough investigation of the different MSTA leaders. Once confronted with FBI interrogations and a wave of arrests, almost instantaneously for survival, the movement made a sudden volte face morphing into a more conservative orientation of Moorish Science emphasising fealty to America. Kirkman-Bey bowdlerised Japanese leanings, as the Moorish Voice now printed articles showing the compatibility of being a faithful Moorish-American while concurrently serving the United States armed forces.

Reincarnationist Moors compromised with Selective Service officials. In November 1941, Eddie Stephens-Bey, a Reincarnationist Moor reported to Fort Dix, New Jersey military training camp brazenly refusing to wear a necktie, swap his fez for an army helmet, consume army chow, or trim his beard, earning him a two-week confinement (Galveston Daily News 1941). Eventually, a middle ground was reached after Reincarnated Moorish leaders granted Private Bey dispensation to relax orthodox religious prohibitions concerning food and the fez; however, his beard was not to be shaved completely but simply trimmed over lightly with clippers. By 1943, even the Reincarnated Moors Americanised their faith system when George Johnson Bey, dramatically transformed from a seditious anti-American propagandist into a patriotic collaborator by furnishing testimony in a federal district court clearly elucidating links between Ashima Takis, Japanese agent provocateurs, and leaders of other seditious black movements who allied themselves with the Axis Powers to produce a revolution by 1944. By irrevocably distancing themselves from more seditious groups, the MSTA averted a similar fate.

In the short run, though shrewd Moorish re-orientation towards American fealty judiciously prevented a similar fate to other repressed, incarcerated religious groups, in the long run this conservative bent only served to disconnect them from the pulse of black urban America which became increasingly livid with the racial hypocrisy of white America by the 1950s. Ironically, the Moorish 'decline' lay not so much in 1929 with Drew's death but rather due to the softening of the MSTA into passivity marked by a growing penchant for white mainstream American acceptance. Concomitantly, Moorish volatility during this post-Drew period caused several MSTA leaders to depart the fold and embrace Sunnī Islamic orthodoxy such as Professor Ezaldeen (ex-James Lomax Bey) and Sheikh Nasir Ahmad (ex-Walter Smith Bey), both of whom 
created and spearheaded their own African-American Sunnī Islamic communities. This elucidated how even so-called heretically deviant groups like the MSTA possessed latently, creative energies to spawn and re-invigorate Sunnī Islamic vitality in tempestuous times.

Beyond the Wars: The MSTA, Civil Rights, and Black Power, $1945^{-1975}$

After the war in 1946, Kirkman Bey used the occasion of the 19th Annual Convention held in 1032 Orleans St, Chicago, Illinois to take stock of the existing state of his movement only to discover a bleak outlook. Officials inspected illegally printed materials from fissiparous rogue Moorish sects. Nevertheless, its response was feeble, merely to read platitude Moorish regulations concerning fraud. Forward-thinking Sheiks from Cleveland, Ohio suggested plans for business expansionism but Chicago officials brusquely dismissed such plans. Most alarmingly, ultra-reactionary, lackadaisical Temple leaders contributed little to a movement in dire need of theological reinvigoration such that Kirkman-Bey caustically impugned thirty-six elderly Adepts in the Moorish National Home as "useless deadheads" (Kirkman-Bey 1946).

The conservative transmogrification towards American jingoism was deepened during a celebration of Drew's birthday in 1949 when the Moorish contribution to American valour in World Wars I and II was embellished. A heroic portrait of Kirkman-Bey was constructed in the Chicago Defender as a fearless war veteran who saw action with the 92nd Division in France in World War I, where he was wounded by bomb fragments in a bloody Argonne forest battle. This set the stage for the MSTA to embrace a conservative placid disposition, steering clear of the civil rights dynamic challenges to Jim Crow's racistinstitutions of the 1950s and 196os since this potentially invited authorities' repression as gleaned from their 1940s' seditious adventurism.

For Reincarnated Moors, continuing their conservative stance was understandable given the desperate need for stable leadership. In 1945, Givens El (Reincarnated Drew Ali II) passed away, creating a leadership vacuum. The faithful first pinned their hopes on the incarcerated Ira Johnson Bey, who reinvented himself as Allah El, but this semi-divine figure remained manacled away in prison despite his retinue's repeated petitions to release their leader citing medical grounds. Hoping to soften the authorities' stance, Allah El proclaimed a pacifist stance prohibiting his followers to participate in wars, instead 'nationalising' as peaceful, civic-minded Moors but to no avail, as he died blind on 5 December 1949. Temporarily, the baton was passed to Sidney 
Rosson El, the National Grand Sheik in Chicago, but soon he made way for George Johnson Bey, Allah El's son, who re-emerged in 1949 to briefly reenergise the movement before controversially abrogating the puritanical inclinations of the Reincarnated community, bringing about heated theological debates and a power struggle before he passed away in 1951.

As leadership in the Reincarnated community frequently changed hands in the 195os, they distanced themselves from the civil rights momentum that took shape in the mid-195os. A Reincarnated Moorish publication, Moorish Review, lambasted the civil rights movement as an unnatural, a "diabolical scheme" to appease African-Americans at best and perpetuate slave-mentality at worst (Jones-El 1956:3-4). Also, they were wary of the white political machine's latent intrigues and influence on the civil rights movement, that merely paid lip service to African-American salvation and hopes. Rather, the Reincarnated Moors banked their hopes externally — and rhetorically—on the Islamicisation of Africa and America in the 196os while dismissing white American destiny as unpropitiously heading towards disaster in the aftermath of the Suez Crisis of 1956, foreshadowing the precarious scenario of being "left alone as the last big Western power in the sea of Asia" (Jones-El 1956:2).

1959 proved a dramatic turning point for the fortunes of the MSTA. As Malcolm x propelled Elijah Muhammad's Nation of Islam (henceforth NOI) towards unprecedented growth, Kirkman-Bey passed away in January of 1959. Moorish leadership was thrust into the hands of F. Nelson Bey, who persisted in alienating them from the civil rights movement, by instructing Moors to be more civic-minded through active participation in communal activities. Still, the passivity lingered as he insisted no evangelising be done, while permitting members to leave the community. This prompted large number of Moors to exit the Temple doors, swapping their fezzes and turbans in exchange for the NOI's bowties and the angrier pro-black ideology offered. On 6 January 1961, Elijah Muhammad replied in a letter to Ferrell-Bey, a Chicago Moor urging "all that believe and follow prophet Ali [Drew] to follow me and you will be successful" in a symbolic transfer of influence from the MSTA to the NOI (Muhammad 1961).

J. Blakeley-Bey, who succeeded F. Nelson Bey as SGAM in 1963, recognised the need to position the MSTA vis-à-vis the NOI's black separatism and civil right movement's integrationist goals. However, Blakeley-Bey's energies were expended untangling messy knotted rivalries. Lacking a strategy to stem the flow of heretics, the SGAM fatalistically drew on Drew's messianic return to salvage the movement reminding that Drew exhorted "I am going to drive the Moors back home to Islam if I have to cut their heads off" (Blakeley-Bey 1964: 1). Despite garbing Drew in proto-Black Power prophetic garb, this proved 
merely rhetorical as it sought only to deal with internal enemies while avoiding larger national, African-American issues.

In 1967, upon witnessing the series of federal civil rights legislations successfully passed, Blakely-Bey vacillated hesitantly towards civil rights. But this attitudinal shift was laboriously slow towards a phenomenon that was already on the wane. On one hand, the SGAM entertained notions of racial integrationism through a future of expanded white Moorish membership, revealing that while the religion may currently be strange to Caucasians, it was not a "closed book" (Hopkins, Jr. 1967: 16). To justify this revisionism to a more racially inclusive one, Blakeley-Bey re-emphasised the Moorish faith's underlying esoteric Theosophical roots, "we co-exist with everyone because we are a religion of love" (Blakeley-Bey 1967: 1). On the other hand, the authenticity of promised bi-racial membership was questionable, given this was only permissible narrowly within the confines of the Temple doors rather than through mass civil protests outside the Temple. Paradoxically, it was Blakeley-Bey's own arcane and millenarian belief in a rigid racial-religious dichotomy between black Asiatic Islam and white Protestantism that hamstrung his own innuendoes about racial integrationism: "give the Europeans the time, and they will force us back out [of Christianity]. They've got 34 years to do it before the big change comes. The big change is the millennium" (Blakeley-Bey 1967:16). Bey's precarious oscillation between integrationism and separationism only bewildered Moorish adherents who perceived his shifts as a sacrilegious bastardisation of Moorish tenets.

In stark contrast, the Reincarnated Moors retained their distrust of civil rights movements' methods and aims. Instead, they began syncretically experimenting with select Sunnī Islamic beliefs that seamlessly dovetailed within Moorish religious principles without compromise. In January 1967 , the community announced that Drew's birthday uncannily coincided with Ramadan. It highlighted Ramadan's significance being the holiest month of the Islamic lunar calendar but concomitantly assured that Ramadan was not be imposed onto his Moorish community and the spiel was only meant for "enlightenment" (Reynold-El 1967). Reincarnated Moors from the 1960s grew acutely aware of the distinct advantages of allying themselves to orthodox Islam given the religio-political significance of weaving themselves to the centre of traditional Islam. Over the next few decades, various Moorish groups have continued to carve open a Sunnī Islamic space within Moorish Temples.

As Black Power militancy emerged in the mid-196os, a hodgepodge of 'ronin Moors' previously affiliated to diverse sects pushed aside theological differences to band together from 1965 to 1972 . Aghast at the staid MSTA of the 196os, and the failure of civil rights legislation to meaningfully impact 
African-Americans, this Moorish ecumenical, activist group was influenced by Black Power's rallying call for black empowerment to organise their own 37th Annual Convention of MSTA in September, 1965 calling for Moorish activism to be at the vanguard of developing model African-American communities.

At the Convention, Joseph Jeffries El excoriated the civil rights movement to preserve the bio-religious and national purity of the Moors, "We Moorish-Americans do not ask for social equality integration because we, as a clean and pure nation descended from the inhabitants of Africa, do not desire to amalgamate or marry into the families of the pale skin nations of Europe" (Jeffries-El 1965: 1) Integration was undesirable from a religious perspective since divine Moors do not serve "the Gods of their religion" (Jeffries-El 1965). By transplanting Drew's words from the Circle Seven Koran and layering it onto the 196os socio-political climate, El effectively transformed Drew into a Black Power prophet, who prophesised the failure of civil rights integrationism and forewarned his posterity against the dangers of racial integration. While rejecting Black Power methods of militancy, Jeffries-El was inspired by the NOI's ten point-program called "What the Muslims Want" and by the Black Panther Party's ten-point-program called "What We Want Now!" and "What We Believe" (Bloom and Martin 2013). El crafted a similar ten-point Moorish manifesto called "Let My People Go" designed to build positive African-American communities. Hence, Jeffries El organised a plethora of businesses and community programmes ranging from heading a government-aided housing construction, moving company and a management company (Tomasson 1973). In September 1967, constructive Moorish empowerment was demonstrated as Brooklyn Moors played peacemaker between Mayor Lindsay, besieged policemen and black rioters on the streets of Brownsville, Brooklyn. MSTA leaders walked into the crowds, talking to angered residents, and cajoling them to discuss matters on MSTA premises with officials where they held a joint news conference with Congress of Racial Equality (CORE) demanding the end of police brutality.

Rufus German Bey, (1909-1984), another charismatic ronin Moorish leader, based himself in Baltimore, Maryland since 1927. Disenchanted at the passive religious orientation, he distanced himself from Chicago's headquarters, instead favouring a more pro-active evangelising Moorish mission for incarcerated African-Americans. Beginning in 1956, German-Bey started the first Moorish Preparation Centre at Lexington, Kentucky Federal Prison and expanded it to over sixty Preparation Centers mainly in Baltimore, Maryland and Washington, D.C. During these crusading visits, German-Bey invited incarcerated African-Americans to Islamism over cake and pastries, initiated their proclamation of Moorish-American nationality and celebrated Moorish holidays. 
Still the Moorish turn towards Black Power empowerment was complex, given Moors publicly maintained an aversion to black cultural pride as unMoorish averring that "there is no dignity in black pride because there is no Negro, black, or colored people attached to the human race. I do not believe in black pride, but in human dignity and in the pride of Allah's creation" (McGee-Bey 1968: 4). In addition, the Moorish distaste for Black Power's militant, confrontational strategies was reasonable for it went against the grain of Drew's advice for civic-minded Moorish members to adhere to all laws.

Yet, the relationship between Black Power and Moorish Science was a dynamic two-way process, as several Black Power nationalist groups borrowed motifs and elements from MstA. Colonel Hassan Jeru-Ahmad leader of two Washington-based Black Power movements, the Blackman's Volunteer Army of Liberation and Blackman's Development Center, prepared for a future race war between his mercenaries and 'whitey' to create an independent central and southern African utopian state called the United Moorish Republic (Mac, Jr. 1971). Jeru-Ahmad's local UMR ameliorated social and economic ills in underprivileged black communities through community security patrols, anti-riot programs, vermin extermination businesses and job skills training. In fact, he envisioned migrating his adherents to Westmoreland County to build a utopian rural community of 500 citizens of the UMR, where he would also establish a Moorish University of Science and Technology (MSUT) as a "port of embarkation" (Delano 1971: 17) for trained black technicians to transfer their knowledge and skills to aid emerging nations in Africa.

In the post-war years, the MSTA was forced to reconfigure itself in complex, pretzel-like directions in response to civil rights and Black Power developments. Though these contortions further weakened the glue holding the disparate Moorish groups together, this generation of Moorish leaders' creative policies have benefitted under-privileged, black urban micro-communities near the MSTA temples by serving their economic, spiritual and psychological needs.

As Black Power momentum waned by the mid-1970s, so too did the MSTA's fortunes flag. The pro-active Moorish ecclesiastical unity of the late 196os proved ephemeral, succumbing to internal fissures over theological faultlines and to the popularity of Elijah Muhamad's ubiquitous black Muslims. Faced with such strains, the MSTA underwent another metamorphosis in orientation. Following decades of misreading by American authorities as a 
cult devoid of authenticity, the Moors over-reacted as Kirkman-Bey's faction reclusively turned inwards, while Reincarnated Moors embraced a hyper-legal anarchism in a desperate attempt to foist their Moorish identity upon various state and federal documents at expense of transgressing the law (Mubashir 2001). Unfortunately as a result of the latter, contemporary Moors have been pejoratively and unfairly stereotyped as criminalised Islamic "paper-terrorists" (Hanson 2015) bent on finagling the American legal system.

The roots of the Moorish legal anarchism traced back to the teachings of C.M. Moseley Bey, an independent, Cleveland-based Moorish renegade in the 1950s and 196os whose followers evaded taxation based on the Moorish-Masonic text, The Clock of Destiny. Its more modern equivalent evolved from the Baltimore Reincarnated Moorish Temple, following a public fallout between the Dingle El siblings (Richardson and Timothy Dingle El) and R. German Bey in 1972. In 1975, Richardson Dingle-El (1910-1992) proclaimed himself as 'Reincarnated Prophet Noble Drew Ali III' while his brother Timothy Dingle-El (1923-1980) declared himself as 'Supreme Grand Resurrector' (Dingle-El 2006: 76-77) after publishing his own religious corpus, The Resurrection of the Moorish Science of Temple of America. Together with Clarence R. Reynolds El, they established a Moorish School of Law and History, Incorporated, No. 13 (henceforth MSHL) that attracted a group of college graduates who meticulously researched American laws, modernised the movement's outlook and reinvigorated Baltimore Temple membership (Amenu-El 2008).

In the early 1970s, the MSHL successfully removed erroneous labels issued by the Maryland Department of Motor Vehicles (M DMV) such as 'negro' or 'black' by re-registering the Moors' licenses. From 1974 to 1976, the MSH L attempted to extend their reach out by petitioning the Black Caucus to discuss their interpretation of President Abraham Lincoln's Emancipation Proclamation, but their request for official meetings were brushed off. The MSHL believed exslaves had never been legally raised to the status of persons, nor had they been properly compensated for their involuntary servitude as intended by Lincoln, such that African-Americans were fleeced of constitutional rights, including a restitution from the government as compensation to colonise and develop "model communities" for Moors (Amenu-El 2008: 6o). Instead, they proposed 'resurrecting' the executive will of Lincoln's Proclamation and the Thirteenth Amendment to the United States constitution with twenty sections.

Rebuffed, they stirred local tax protests such that arrests of felonious Moors charged for filing tax-withholding statements and violation of property laws began surfacing in newspapers in Baltimore and Philadelphia in the late 1970s and early 1980s. While such cases mystified court officials, this turn towards legalistic anarchy should be contextualised as the by-product of earlier 
Selective Service officials' politicisation of Moors to the Kafkaesque maze of world of acts, laws and statutes in the 1940s and 1950s as well as Washington officials' brusque dismissal of the MSHL in the 1970s. This snowballed into a mutual misunderstanding where court officials grew increasingly indifferent to Moors' religious traditions, despite the Moors' legal defiance stemming from the government's own policies in the first place. Curiously, the Reincarnated Moors' hyper-legalistic anarchy represented a rupture from Drew's insistence on adherence to all laws in the past and myopic oversight on the larger implications of tarnishing the Moorish faith in the future.

For German-Bey, dissociation from the Reincarnated Moors gave birth to a phase of Panglossian growth for most of the 1970s, before strategic miscalculations abraded initial optimism. By 1978, his prison-proselytisation project bore fruit as healthy numbers of incarcerated Moors filed prison-initiated court suits demanding their rights for a spiritual co-ordinator, religious literature and prayer arrangements in Baltimore's State Penitentiary (Hyer 1978). In the same year, German-Bey successfully organised a National Convention in the Hopkins Room of the Civic Centre in Baltimore, Maryland, commemorating the 5oth Golden Jubilee Anniversary of the MSTA transferring the focal point of Moorish activism from Chicago to Baltimore (Oishi 1978). Buoyant, German-Bey legally re-styled his Baltimore Temple No. 13 as the bona fide and de facto Temple No. 1, but this only expended his energy and resources in a protracted legal imbroglio from 1978 to 1982 (Way-El 2011).

To complicate matters further, the boundaries between past-criminality and present-disciplined Moorish lifestyle were amorphously fluidic such that the Moorish faith-system became criminalised. Jeff Fort's (b. 1947) conversion to the MSTA elucidated the cross-fertilisation of organised crime networks and Moorish faith systems, giving birth to Imam Malik Kaaba El's El Rukn Moorish Science Temple in the 1980s. Not only did the literal translation from Arabic, El Rukn and Kaaba, into English-'foundation' and 'black stone', respectively_provided a powerful double-barrelled symbolic connection, projecting the El Rukns retrospectively back to its street roots as well as spiritually coupling his movement to the site of orthodox Islam's holiest shrine, Moorish tropes and motifs were skilfully scrambled into a complex code used over the telephone to communicate with associates beyond prison walls. For example, MSTA's core principles were encrypted with secret meanings-'love' represented one, one hundred, or one thousand, 'love-truth' meant two, two hundred, or two thousand, and 'justice' meant weapon - and used in various numerical combinations to be deciphered by associates, as Fort operated a major narcotics ring while ensconced in a federal penitentiary in Bastrop, Texas (Blau and O'Brien 1991). 
Though the El Rukns evolved to Sunnify their doctrines by 1985, their criminal activities continues to taint MSTA's reputation as fezzed pseudo-Muslims involved with drugs, racketeering, witness intimidations and occasional straying into international terror when accepting a multi-million dollar contract from Moammar Gadhafi's Libyan government (Possley 1987). The demonisation of MSTA's reputation was perpetuated by arrest of other controversial Moorish leaders in the early 199os such as Jerry Lewis-Bey, a St. Louis Sheik imprisoned for a decade long murderous criminal enterprise that handled cocaine traffic. In 1993, Clarence Rodney Hampton-El (1938-2014), a Brooklyn-born Moor's highly publicised arrest for conspiring to bomb several buildings in New York reinforced the MSTA's standing in the public as a grotesquely menacing organisation (Clines 1993). The underlying lesson gleaned was the sheer fluidity through which these protagonists symbiotically intertwined their personae between Moorish Science, Sunnī Islam, international jihadist inclinations and altruistic community-activism as well as between boundaries of legality.

In the 1990s and 2000, Moorish synonymity with unbridled "paper terrorism" returned, where Moors claimed immunity from American laws owing to an imagined Moorish sovereign status (Nelson 2011). This phenomenon now rooted from nefarious leaders' surreptitious pseudo-Moorish teachings. In the mid-199os, Malachi York and his Ansarullah community's alchemic transmogrification into Moorish cultic movements, the Yamassee Native American Moors of the Creek Nation and the United Nuwaubian Nation of Moors, introduced the bogus notion of a tax-free Moorish haven (Moser 2002). York's ideas was fetishised further by Verdiacee Turner, a dreadlocked Louisiana-based 'Washitaw Empress' who spuriously sold her followers gobbledygook Washitaw documents ranging from driver registration plates, registrations, birth certificates and passports promising to insulate holders from being sued and taxed.

In the 2ooos with the advent of the Internet, cyber Moorish Prophets brought such insidious doctrines to a much wider public audience. In particular, Tej Tarik Bey, a Harlem-based Moor have extensively used the online pulpit of websites and YouTube sermons to propagate his Moorish sovereign doctrines. Mainstream Moors have lampooned Tarik-Bey for confusing Moors and infuriating authorities but sadly, such fallacious teachings continues to gain traction among both Moors and non-Moors, oblivious of Drew's insistence on MSTA members' obeisance for legal statutes. Usually desperate for an escapist 
route out of financial ruin, these naïve Moorish paper terrorists usually end accused for tax fraud, illicit trespassing into vacant houses, filing bogus liens and lawsuits against officers and prosecutors.

Though the media has caricaturised the MSTA as criminalised fanatics and membership diminishing, all is not lost. Other black religious nationalist groups like the NOI, Five Percenter Nation and Ansarullah Community continue to pay homage to Noble Drew Ali as their ideological progenitor for being the Original Asiatic Muslim. Black hip hop artists such as Nas, Wu Tang Clan, Mos Def, and Nick Cannon have all referenced Noble Drew Ali's ideas, Moorish-tropes and iconography in their lyrics, thus popularising and preserving the memories of the religious innovator to millions of consumers. The few thousand contemporary Moors need not worry about the future, all they need is to reach back to their own past- and live out the highest, purest form of Moorish principles of "learning to love, instead of hate."

\section{References}

Abdat, F. 2014. "Before the Fez: The Life and Times of Noble Drew Ali, 1886-1924." Journal of Race, Ethnicity and Religion. 5:8, 1-39.

Abdat, F. 2015. "Sheiks of Sedition: Father Prophet Mohammed Bey, Mother Jesus Rosie Bey and Kansas City's Moors, 1933-1945." Journal of Religion and Violence. 3:1, 7-33. Abu Shouk, A.I., J.O. Hunwick, and R.S. O' Fahey. 1997. "A Sudanese Missionary to the United States: Satti Majid, Shaykh al-Islam in North America and His Encounter with Noble Drew Ali, Prophet of the Moorish Science Temple Movement." Sudanese Africa. 8, 137-191.

Ali, N.D. 1926. "Moorish Temple of Science Incorporation Papers." Moorish Science Temple of America Collection 1926-1967. New York Public Library, Schomburg Center for Research in Black Culture.

Ali, N.D. 1928. "Moorish Science Temple of America Incorporation Papers." Moorish Science Temple of America Collection 1926-1967.

Ali, N.D. 1928. Moorish Guide. 1:1, August.

Allen, Jr., E. 1994. "When Japan was Champion of the Darker Races: Satokata Takahashi and the Flowering of Black Messianic Nationalism." The Black Scholar. 24, 23-46.

Amenu-El, R. 2008. The Negro, The Black, The Moor. Baltimore, MD: Gateway Press, Inc. Blakeley-Bey, J. 1964. "Supreme Grand Advisor's Plea to the Grand Body in 1964." Blau, R. and J. O' Brien. 1991. "Rise and Fall of El Rukn Jeff-Fort's Evil Empire." Chicago Tribune. 8 September.

Bloom, J. and E.W. Martin. 2013. Black Against Empire: The History and Politics of the Black Panther Party. Berkeley: University of California Press. 
Bowen, P. 2011. "Abdul Hamid Suleiman and the Origins of the Moorish Science Temple." Journal of Race, Ethnicity and Religion. 12:13, 1-54.

Bowen, P. 2013. "Notes on the MSTA Schisms in Detroit and Pittsburgh, 1928-1929." Paper presented to Ali's Men East Coast Moorish Brotherhood Summit, Baltimore, Maryland, 2013.

Bowen, P. 2014. "Prince D. Solomon and the Birth of African-American Islam." Journal of Theta Alpha Kappa, 38:1, 1-19.

Bowen, P. 2017. A History of Conversion to Islam in the United States, Volume 2: The African American Islamic Renaissance, 1920-1975. Leiden and Boston: Brill.

Clines, F.X. 1993. "Spector of Terror: U.S.-Born Suspect in Bombing Plots: Zealous Causes and Civic Roles." New York Times. 28 June.

"Could Bend Bars, Still Sat in Jail." 1916. Newark Evening News, 27 June.

Curtis IV, E. 2002. Islam in Black America: Identity, Liberation and Difference in African-American Islamic Thought. New York: State University of New York Press.

Curtis IV, E. 2009. "Debating the Origins of the Moorish Science Temple: Towards a New Cultural History." In E. Curtis IV and D.B. Sigler eds, The New Black Gods: Arthur Huff Fauset and the Study of African American Religions. Bloomington and Indianapolis: Indiana University Press, 70-86.

Delano, F. 1971. "Westmoreland is Stepping Stone in Vision of Col. Hassan." The Free Lance-Star. 24 February.

Dingle-El, T. 2006. The Resurrection, of the Moorish Science Temple of America, Inc. The Truth: Be Yourself and Not Somebody Else. Chicago, IL: Magribine Press.

Dorman, J.S. 2009. "A True Moslem is a True Spiritualist: Black Orientalism and Black Gods of the Metropolis." In E. Curtis IV and D.B. Sigler eds, The New Black Gods: Arthur Huff Fauset and the Study of African American Religions. Bloomington and Indianapolis: Indiana University Press, 116-142.

Drew, T. and J.W. Drew. 2013. 1900 United States Census Records.

Drew, T. 1918. World War I Draft Registration Record.

Drew, T. 2013. 1920 United States Census Records.

Federal Bureau of Investigation File on MstA. At https://vault.fbi.gov/Moorish\%2O Science\%2oTemple\%2oof\%2oAmerica. Accessed 28/12/2014.

Folsom-Bey. 1941. "We Have the Rights." Moorish Voice. 2 August.

Haddad, Y. and J.I. Smith. 1993. Mission to America: Five Islamic Sectarian Communities in North America. Florida: University Press of Florida.

Hanson, B. 2015. "Fraud, Squatting Frequently Linked to Moorish Religion Followers." WSOV-TV, November 19. At http://www.wsoctv.com/news/news/special-reports/ fraud-squatting-frequently-linked-moorish-religion/npQ8t/. Accessed o1/o2/2015.

Hopkins, Jr, A.D. 1967. “Solitary Religious Sect Lives, Plans Future in Prince George.” The Progress-Index. 15 January. 
Hyer, M. 1978. "Muslims in Maryland Jails Negotiate for own Chaplains, Diet, Prayer Sites." The Washington Post. 4 July.

Jeffries-El, J. 1965. "37th Annual Convention Moorish Science Temple of America Inc." Moorish Science Temple of America Collection 1926-1967.

Jones El, E. 1956. "They Say Police Action: News in Review." Moorish Review. November. Kirkman-Bey, C. 1946. "Minutes of the 19th Annual Convention Sep 1946." Moorish Science Temple of America Collection 1926-1967. New York Public Library, Schomburg Center for Research in Black Culture.

Lincoln, C.E. 1994. The Black Muslims in America. Grand Rapids, MN: Wm. B. Eerdmans Publishing.

Mack Jr., J. 1971. "Unlikely Allies Join in War Against Drugs." The Dispatch. 28 January.

Marsh, C. 200o. The Lost-Found Nation of Islam in America. Maryland: Scarecrow Press. McCloud, A. 1994. African American Islam. New York and London: Routledge.

McGee-Bey, J. 1968. "Letters to the Editor." Chicago Defender. 10 June.

"Mohammedan Sheik Allows Recruit to Get Haircut, Shave." 1941. Galveston Daily News. 18 June.

Moser, B. 2002. "United Nuwaubian Nation of Moors Meet its Match in Georgia." Southern Poverty Law Centre. 20 September.

Mubashir, D.W. 2001. "Forgotten Fruit of the City: Chicago and the Moorish Science Temple of America." Cross Currents. 51:1, 6-20.

Muhammad, E. 1961. "Letter from Muhammad's Mosque No. 2 to L. Ferrell Bey." 6 January.

Nelson, L. 2011. "Members of 'Moorish' Groups and Other Black Americans Are Taking Up the Ideas of the Radical 'Sovereign Citizens' Movement." SPLC. 24 August.

Oishi, G. 1979. "Mine Eyes Have Seen the Glory of Noble Drew Ali." The Baltimore Sun. 31 October.

Possley, M. 1987. "New Indictment Charges Gang With Terrorism." Chicago Tribune, 3 April.

Reynold-El, N. 1967. "Ramadan: Letter from the President." January.

Tomasson, R.E. 1973. "A Minister Spurs Housing in Brownsville." New York Times. 8 April. Vale, R. 1934. "Islam Calls in Lombard St.: Thousands Flocking to Banner of Chicago Mystic Who Claims to Be Mohammed Reincarnated." Philadelphia Sunday News. 25 October.

Way-El, 2011. Noble Drew Ali and The Moorish Science Temple of America: The Movement That Started It All. Chicago: Lulu.com.

Wilson, P.L. 1993. Sacred Drift: Essays on the Margins of Islam. San Francisco, CA: City Light Books. 